\title{
Article \\ Agronomic Assessment of Fibrous Flax and Linseed Advanced Breeding Lines as Potential New Varieties
}

\author{
Marcin Praczyk * and Katarzyna Wielgusz
}

Citation: Praczyk, M.; Wielgusz, K Agronomic Assessment of Fibrous Flax and Linseed Advanced Breeding Lines as Potential New Varieties. Agronomy 2021, 11, 1917. https:// doi.org/10.3390/agronomy11101917

Academic Editor: Stefano Amaducci

Received: 10 August 2021

Accepted: 21 September 2021

Published: 24 September 2021

Publisher's Note: MDPI stays neutral with regard to jurisdictional claims in published maps and institutional affiliations.

Copyright: (c) 2021 by the authors. Licensee MDPI, Basel, Switzerland. This article is an open access article distributed under the terms and conditions of the Creative Commons Attribution (CC BY) license (https:/ / creativecommons.org/licenses/by/ $4.0 /)$.
Department of Breeding and Agricultural Technology for Fibrous and Energy Plants, Institute of Natural Fibres and Medicinal Plants National Research Institute, Wojska Polskiego 71 b, 60-630 Poznan, Poland; katarzyna.wielgusz@iwnirz.pl

* Correspondence: marcin.praczyk@iwnirz.pl

\begin{abstract}
The aim of the study was to determine the breeding value of advanced lines of fibrous flax and oilseed flax (linseed) on the basis of comparative experiments with reference varieties. In field experiments conducted in 2019-2020, the HDH line of fibrous flax and the R26 linseed line were assessed in terms of significant phenotypic traits and also traits affecting the yield structure. Due to the fundamentally different weather conditions in the growing seasons of 2019 and 2020, it was also possible to determine the susceptibility of the studied genotypes of flax to climatic stress factors. The obtained results showed the high breeding value of the HDH line as a potential new variety of fibrous flax. The R26 line did not exceed the reference varieties in terms of the traits essential for the oily form of the cultivated flax cultivars, but it was characterized by a favorable morphological and yield-forming structure for dual purpose varieties. Moreover, both assessed lines showed high resistance to unfavorable climatic conditions.
\end{abstract}

Keywords: fiber flax; linseed; new varieties

\section{Introduction}

Flax (Linum usitatissimum L.) is a species with very diverse application potential. The raw materials obtained from the cultivation of flax are used, among others in the pharmaceutical, food, textile and energy industries. Flax seeds, which are the richest plant source of omega-3 polyunsaturated fatty acids, are characterized by excellent healthpromoting qualities and are often used as an ingredient in a diet recommended for the prevention of many diseases [1,2]. The results of research confirming the anti-cancer properties of substances contained in the seeds and oil of flax seem to be particularly valuable [2-4]. Linen fiber is widely known for its excellent properties. Linen clothing has a positive effect on the human body without causing allergies and strengthens the immune system $[5,6]$. It limits sweating and decreases body temperature. Characteristic of flax fiber clothing is also that it does not accumulate electrostatic charges on the surface [7].

The total cultivation area of fiber flax in the world is approximately 260,000 ha, while that of oilseed flax (linseed) is approximately 3,200,000 ha [8]. The main producers of fibrous flax are France, Russia and Belarus, while oilseed flax (linseed) are Kazakhstan, Canada, Russia and China [8].

The breeding of flax varieties, which has been carried out for many years, has led to the distinction of two basic cultivated forms: fibrous and oily. Morphological differences between them mainly concern plant height, panicle shape, 1000 seeds weight, capsule size and yield structure $[9,10]$. Oily plants are shorter, and stems are more branched. They are also characterized by a larger capsule size and a higher 1000 seed weight. The basic raw material obtained from the linseed varieties are seeds; therefore, the seed yield of these varieties is significantly higher than that of fibrous varieties. Fibrous varieties, in turn, are characterized by a much higher yield of straw, from which the fiber is obtained. The differences between the fibrous and oily forms of flax also occur in terms of climatic and 
agrotechnical requirements. This makes it necessary to strictly target flax cultivation at fibrous and linseed plantations, which limits their profitability. Therefore, many breeding programs now focus on producing dual purpose varieties that combine high seed yield with high fiber yield [11-13].

One of the main problems of breeding new varieties of flax is the low variability of the most important functional traits [14,15]. This is generally caused by the low genetic diversity of cultivated forms. This applies in particular to fibrous flax. Although the genus Linum has about 200 species significantly different from each other in terms of many traits, the cultivated form is only one species-flax (Linum usitatissimum L.). The variability of functional traits in cultivated forms could be increased by outcrossing with wild species, but the testing of these species for the most important economic traits showed little usefulness as prospective initial materials. The identification of breeding lines, surpassing the currently cultivated varieties so far in terms of yielding and morphological traits, positively correlated with the yield structure, as well as showing greater resistance to biotic and abiotic stresses, is an important stage of biological progress.

In this article, we present the results of field experiments with our two breeding lines-HDH (fibrous flax) and R26 (linseed), which are characterized by their high yielding potential. In these studies, selected functional traits of new breeding lines and seven reference varieties were compared. Moreover, the functional characteristics of the R26 line were assessed as a potential new dual-purpose variety that could be recommended for cultivation.

\section{Materials and Methods}

\subsection{Plant Material}

HDH and R26 breeding lines were obtained by conventional breeding methods, characteristic of self-pollinating species. The parental varieties were crossed, and the obtained hybrids were reproduced. Two analogous field experiments were carried out. The first compared the HDH line with seven fibrous flax varieties (Table 1), while the second compared the R26 line with seven oilseed flax (linseed) varieties (Table 2).

Table 1. Examined fibre flax varieties.

\begin{tabular}{cc}
\hline Variety & Country of Origin \\
\hline Evea & France (GIE Linea Semences de Lin Company) \\
Filea & France (GIE Linea Semences de Lin Company) \\
Novea & France (GIE Linea Semences de Lin Company) \\
HDH ${ }^{1}$ & Poland (Institute of Natural Fibers and Medicinal Plants) \\
Jan & Poland (Institute of Natural Fibers and Medicinal Plants) \\
Sara & Poland (Institute of Natural Fibers and Medicinal Plants) \\
Modran & Poland (Institute of Natural Fibers and Medicinal Plants) \\
Selena & Poland (Institute of Natural Fibers and Medicinal Plants) \\
\hline
\end{tabular}

${ }^{1}$ The new breeding line.

Table 2. Examined linseed varieties.

\begin{tabular}{cc}
\hline Variety & Country of Origin \\
\hline CJ 1016 & Poland (Center for National Genetic Resources of the Institute of \\
Altess & Plant Breeding and Acclimatization) \\
Festival & France (GIE Linea Semences de Lin Company) \\
Marquise & France (Laboulet Semences) \\
Merlin & France (GIE Linea Semences de Lin Company) \\
Jantarol & France (Laboulet Semences) \\
Bukoz & Poland (Plant Breeding Strzelce) \\
R26 $^{1}$ & Poland (Institute of Natural Fibers and Medicinal Plants) \\
\hline
\end{tabular}

${ }^{1}$ The new breeding line. 


\subsection{Experimental Site and Field Experiment}

Field experiments were carried out in the years 2019-2020 at the experimental station of the Institute of Natural Fibers and Medicinal Plants in Pẹtkowo, Poland $\left(52.2167^{\circ} \mathrm{N}\right.$; $17.2667^{\circ} \mathrm{E}$ ). The previous crop was winter wheat. The tested varieties of flax were sown in three replications, arranging the objects using the random block method. The sowing density for fibrous varieties was 2000 seeds $/ \mathrm{m}^{2}$, while for oil varieties it was 600 seeds $/ \mathrm{m}^{2}$. The row spacing in both experiments was $15 \mathrm{~cm}$. The seeds were sown with a self-propelled plot drill. The area of the experimental plots was set at $10 \mathrm{~m}^{2}$. During the vegetation period, agricultural practices typical for flax cultivation were applied. After harvesting the plants from the field, biometric measurements were carried out.

The yield was determined on the basis of testing all plants harvested from each plot. Morphological measurements were made on 20 randomly selected plants from each plot. Total, technical and panicle length was determinant with an accuracy of $1 \mathrm{~cm}$. while stem diameter had an accuracy of $0.1 \mathrm{~mm}$.

The breeding lines and varieties of flax were compared in terms of the following traits:

- Total yield - weight of the whole harvested plants, including roots;

- Straw yield-plant weight after deseeding and root removal;

- $\quad$ Seed yield;

- Total length - the distance from the beginning of the roots to the top of the panicle was established as the total length of the plants;

- Technical length - the technical length of plants was determined by measuring plants from the root neck to the first branching of the panicle;

- Panicle length.

For linseed varieties, the number of seed capsules was additionally determined, while for fibrous varieties, the diameter of the stem was measured by measuring the circumference of the middle part of the stems. Measurements were conducted with an electronic caliper. Results are reported as means for each combination. The yield units were converted to $\mathrm{dt} \mathrm{ha}^{-1}$.

\subsection{Weather and Soil Conditions}

Weather conditions were given according to the readings of the weather station AsterMet (logger SM-076) in Petkowo. The plots were prepared on medium arable soil, with light loamy sand type and a neutral $\mathrm{pH}$. The content of basic chemical elements in the soil was as follows: C organic $-1.62 \%, \mathrm{~N}-0.128 \%, \mathrm{P}-248.5 \mathrm{mg} \mathrm{kg}^{-1}, \mathrm{~K}-223.0 \mathrm{mg} \mathrm{kg}^{-1}$, $\mathrm{Mg}-60.0 \mathrm{mg} \mathrm{kg}^{-1}$. The following fertilization was applied: $\mathrm{N}-34 \mathrm{~kg} \mathrm{ha}^{-1}, \mathrm{P}-92 \mathrm{~kg} \mathrm{ha}^{-1}$, $\mathrm{K}-160 \mathrm{~kg} \mathrm{ha}^{-1}$.

\subsection{Statistical Analysis}

The results were analyzed statistically. Comparative analysis was performed using one-way analysis of variance (ANOVA). In the case of failure to meet the assumption of homogeneity of variance (verified with Levene's test), the Welch F test was used. Tukey's RIR test was used for multiple comparisons. The results were considered statistically significant when the calculated test probability met the inequality $p \leq 0.05$. The calculations were made in the Statistica 10.0 package by Statsoft Poland. Detailed data from statistical calculations are presented in Supplementary Materials.

\section{Results}

\subsection{Weather Conditions}

The research was conducted under various climatic conditions. The year 2019 was characterized by a large deficit of water. The total amount of precipitation was $257.4 \mathrm{~mm}$, while in 2020, total precipitation was $648.9 \mathrm{~mm}$. The average daily temperatures in both seasons were similar. The details of climatic conditions are presented in Table 3. 
Table 3. Precipitation and average daily temperature in Pętkowo experimental station.

\begin{tabular}{ccccc}
\hline \multirow{2}{*}{ Month } & \multicolumn{2}{c}{ Precipitations $[\mathbf{m m}]$} & \multicolumn{2}{c}{ Temperature $\left.{ }^{\circ} \mathbf{C}\right]$} \\
\cline { 2 - 5 } & $\mathbf{2 0 1 9}$ & $\mathbf{2 0 2 0}$ & $\mathbf{2 0 1 9}$ & $\mathbf{2 0 2 0}$ \\
\hline January & 25.6 & 11.1 & 0.07 & 3.14 \\
\hline February & 12.6 & 52.4 & 3.48 & 4.93 \\
\hline March & 32.9 & 22.4 & 6.57 & 5.27 \\
\hline April & 6.5 & 5.6 & 10.73 & 9.59 \\
\hline May & 144.0 & 114.9 & 12.40 & 11.89 \\
\hline June & 1.0 & 159.5 & 22.77 & 18.29 \\
\hline July & 22.0 & 76.3 & 19.53 & 18.85 \\
\hline August & 4.8 & 75.9 & 21.17 & 20.23 \\
\hline September & 5.4 & 48.8 & 14.65 & 15.75 \\
\hline October & 1.0 & 57.6 & 11.20 & 11.10 \\
\hline November & 0.8 & 5.2 & 6.68 & 6.35 \\
\hline December & 0.8 & 19.2 & 3.79 & 2.67 \\
\hline & Total: 257.4 & Total: 648.9 & Average: 11.09 & Average: 10.67 \\
\hline
\end{tabular}

The mentioned differences mainly concerned the amount of rainfall in the vegetation period (April-August). The year 2019 was very unfavorable for flax cultivation. The sum of rainfall in the period from April to August was $173.5 \mathrm{~mm}$, which was $85.5 \%$ of the perennial average. The amount of precipitation was very unevenly distributed. May was particularly unfavorable in this respect, with heavy rainfall. In turn, the year 2020 was characterized by very favorable weather for flax cultivation. Precipitation, in numbers close to the perennial average rainfall, was evenly distributed (Figure 1).

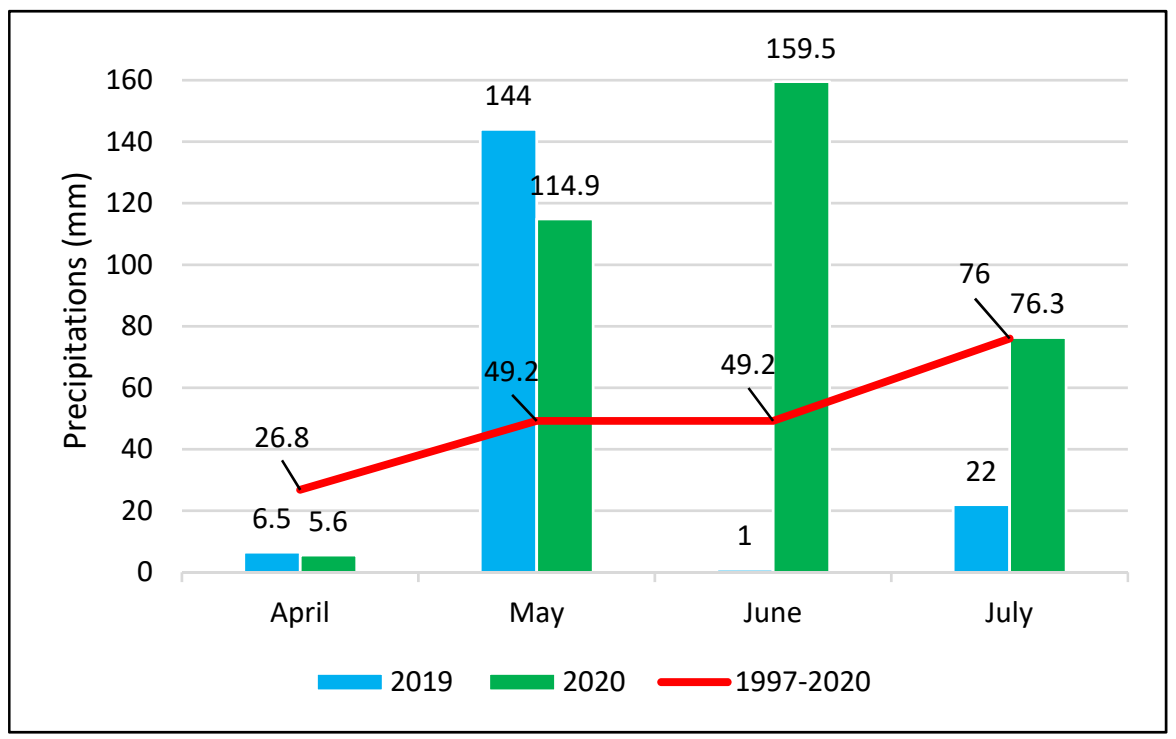

Figure 1. Average monthly precipitation in 2019 and 2020 in the period from April 1 to July 31, compared to the average for the years 1997-2020.

\subsection{Field Experiments with Fibrous Flax Varieties}

The comparison of the growth and yielding of the new $\mathrm{HDH}$ breeding line and seven reference cultivars was carried out in two growing seasons with extremely different amounts of precipitation. In dry 2019, rainfall at that time was $183 \mathrm{~mm}$ lower compared to 2020. In both research seasons, the plants of the HDH line were characterized by the 
highest plant height and the highest technical stem length among all the tested objects varieties (Table 3). In the dry season (2019), the height of fibrous flax plants was on average $19 \%$ lower compared to the season with more precipitation (2020), while the technical length of the stems was even $24 \%$ shorter. In individual seasons, the HDH line reached a height of $71.3 \mathrm{~cm}$ and $91.07 \mathrm{~cm}$, respectively. Statistical analysis showed that in 2019 the plant heights of the HDH line were significantly higher in comparison to the three reference varieties (Evea, Filea, Jan), while the technical length of plants of the HDH line was significantly higher than the six reference varieties. The other tested cultivars were significant, except for the Selena cultivar.

In 2020, significant differences in plant height were found between the HDH line and Evea, Filea, Jan and Sara cultivars, and in the technical length of the stems, significant differences also concerned the Modran cultivar. Plants of the HDH line were characterized by short panicles compared to the other tested varieties. In 2019, only Novea and Selena cultivars had panicles of similar lengths, while the remaining reference cultivars produced significantly longer panicles, whereas in 2020, only the Filea cultivar produced significantly longer panicles compared to the HDH line. In 2020, significant differences in plant height were found between the HDH line $(91.07 \mathrm{~cm})$ and the Evea $(76.73 \mathrm{~cm})$, Filea $(84.43 \mathrm{~cm})$, Jan $(82.03 \mathrm{~cm})$ and Sara $(79.93 \mathrm{~cm})$ varieties. In the technical length of the stems (distance from the root neck to the firs panicle branching), plants of the HDH line were significantly higher than Evea, Filea, Jan, Sara and Modran. Plants of the HDH line were characterized by short panicles compared to the other tested varieties (the mean panicle length of $\mathrm{HDH}$ line was $10.91 \mathrm{~cm}$ in 2019 and $10.4 \mathrm{~cm}$ in 2020). In 2019, only Novea (12.32 cm) and Selena $(11.84 \mathrm{~cm})$ varieties had panicles with similar lengths, while the remaining reference varieties produced significantly longer panicles. In 2020, only the Filea cultivar produced significantly longer panicles compared to the $\mathrm{HDH}$ line $(12.57 \mathrm{~cm})$.

In 2019, the diameter of the stem of fibrous flax varieties ranged from $1.55 \mathrm{~mm}$ to $1.64 \mathrm{~mm}$, and these differences were statistically insignificant. In 2020, most varieties produced thicker shoots ranging in diameter from $1.49 \mathrm{~mm}$ to $1.78 \mathrm{~mm}$. The shoots with the largest diameter were found in plants of the $\mathrm{HDH}$ line and, compared to the cultivars Filea, Novea, Jan and Sara, were statistically significant (Table 4).

Table 4. Means, standard deviation and ranges for total, technical, panicle length and stem diameter of the fibrous flax varieties.

\begin{tabular}{|c|c|c|c|c|c|c|c|c|c|}
\hline \multirow{2}{*}{ Traits } & \multirow{2}{*}{ Year - } & \multicolumn{8}{|c|}{ Variety } \\
\hline & & Evea & Filea & Novea & $\mathrm{HDH}$ & Jan & Sara & Modran & Selena \\
\hline \multirow{2}{*}{$\begin{array}{c}\text { Total } \\
\text { length }(\mathrm{cm})\end{array}$} & 2019 & $\begin{array}{c}66.28 \pm 4.74 \\
\quad(52-75)\end{array}$ & $\begin{array}{c}65.80 \pm 4.52 \\
\quad(55-77)\end{array}$ & $\begin{array}{c}69.80 \pm 4.93 \\
\quad(61-82)\end{array}$ & $\begin{array}{c}71.37 \pm 5.42 \\
(59-84)\end{array}$ & $\begin{array}{c}66.75 \pm 7.59 \\
(51-85)\end{array}$ & $\begin{array}{c}68.87 \pm 4.27 \\
\quad(57-76\end{array}$ & $\begin{array}{c}70.47 \pm 4.46 \\
(60-84)\end{array}$ & $\begin{array}{c}71.15 \pm 5.81 \\
(58-83)\end{array}$ \\
\hline & 2020 & $\begin{array}{c}76.73 \pm 9.14 \\
\quad(58-90)\end{array}$ & $\begin{array}{c}84.43 \pm 7.17 \\
\quad(66-94)\end{array}$ & $\begin{array}{c}87.27 \pm 5.94 \\
\quad(74-97)\end{array}$ & $\begin{array}{c}91.07 \pm 5.34 \\
(81-104)\end{array}$ & $\begin{array}{c}81.97 \pm 6.78 \\
(66-95)\end{array}$ & $\begin{array}{c}79.93 \pm 6.68 \\
\quad(65-90)\end{array}$ & $\begin{array}{c}86.97 \pm 4.62 \\
(77-99)\end{array}$ & $\begin{array}{c}90.2 \pm 7.71 \\
\quad(72-106)\end{array}$ \\
\hline \multirow{2}{*}{$\begin{array}{l}\text { Technical } \\
\text { length }(\mathrm{cm})\end{array}$} & 2019 & $\begin{array}{c}52.43 \pm 4.62 \\
\quad(40-65)\end{array}$ & $\begin{array}{l}51.96 \pm 4.18 \\
\quad(40-65)\end{array}$ & $\begin{array}{c}57.48 \pm 4.12 \\
\quad(47-65)\end{array}$ & $\begin{array}{c}60.47 \pm 4.73 \\
\quad(50-70)\end{array}$ & $\begin{array}{c}54.09 \pm 6.54 \\
(37-67)\end{array}$ & $\begin{array}{c}56.13 \pm 4.20 \\
\quad(44-67)\end{array}$ & $\begin{array}{l}57.96 \pm 3.71 \\
\quad(50-72)\end{array}$ & $\begin{array}{c}59.41 \pm 4.57 \\
\quad(49-68)\end{array}$ \\
\hline & 2020 & $\begin{array}{c}66.20 \pm 7.95 \\
(51-79)\end{array}$ & $\begin{array}{c}71.87 \pm 6.16 \\
(57-83)\end{array}$ & $\begin{array}{c}76.07 \pm 5.54 \\
\quad(66-84)\end{array}$ & $\begin{array}{c}80.67 \pm 5.67 \\
(70-95)\end{array}$ & $\begin{array}{c}73.47 \pm 6.10 \\
(60-84)\end{array}$ & $\begin{array}{c}69.9 \pm 5.4 \\
(60-78)\end{array}$ & $\begin{array}{c}74.93 \pm 3.71 \\
\quad(68-85)\end{array}$ & $\begin{array}{c}80.27 \pm 7.11 \\
(60-93)\end{array}$ \\
\hline \multirow{2}{*}{$\begin{array}{c}\text { Panicle } \\
\text { length }(\mathrm{cm})\end{array}$} & 2019 & $\begin{array}{l}13.85 \pm 3.07 \\
\quad(5-20)\end{array}$ & $\begin{array}{l}13.84 \pm 3.32 \\
\quad(5-25)\end{array}$ & $\begin{array}{c}12.32 \pm 3.65 \\
\quad(7-32)\end{array}$ & $\begin{array}{l}10.91 \pm 2.44 \\
\quad(6-19)\end{array}$ & $\begin{array}{c}12.65 \pm 3.79 \\
(3-22)\end{array}$ & $\begin{array}{c}12.73 \pm 2.78 \\
\quad(6-22)\end{array}$ & $\begin{array}{l}12.51 \pm 2.58 \\
\quad(3-19)\end{array}$ & $\begin{array}{c}11.63 \pm 2.88 \\
(6-21)\end{array}$ \\
\hline & 2020 & $\begin{array}{l}10.53 \pm 2.79 \\
\quad(7-17)\end{array}$ & $\begin{array}{c}12.57 \pm 3.07 \\
(8-19)\end{array}$ & $\begin{array}{c}11.2 \pm 2.38 \\
(7-16)\end{array}$ & $\begin{array}{c}10.4 \pm 2.36 \\
\quad(5-15)\end{array}$ & $\begin{array}{c}8.5 \pm 2.79 \\
(2-17)\end{array}$ & $\begin{array}{c}10.03 \pm 2.67 \\
\quad(5-15)\end{array}$ & $\begin{array}{l}12.03 \pm 2.30 \\
\quad(8-17)\end{array}$ & $\begin{array}{c}9.93 \pm 3.24 \\
\quad(5-17)\end{array}$ \\
\hline \multirow{2}{*}{$\begin{array}{l}\text { Stem } \\
\text { diameter } \\
(\mathrm{mm})\end{array}$} & 2019 & $\begin{array}{c}1.59 \pm 0.18 \\
(1.3-2.1)\end{array}$ & $\begin{array}{c}1.58 \pm 0.25 \\
(1.1-2.3)\end{array}$ & $\begin{array}{c}1.5 \pm 0.21 \\
(1.1-2.1)\end{array}$ & $\begin{array}{c}1.6 \pm 0.19 \\
(1.4-2.2)\end{array}$ & $\begin{array}{c}1.64 \pm 0.27 \\
(1.1-2.3)\end{array}$ & $\begin{array}{c}1.56 \pm 0.19 \\
(1.1-2.0)\end{array}$ & $\begin{array}{c}1.55 \pm 0.18 \\
(1.2-2.0)\end{array}$ & $\begin{array}{c}1.58 \pm 0.22 \\
(1.1-2.0)\end{array}$ \\
\hline & 2020 & $\begin{array}{c}1.52 \pm 0.23 \\
(1.0-2.0)\end{array}$ & $\begin{array}{c}1.74 \pm 0.27 \\
(1.4-2.5)\end{array}$ & $\begin{array}{c}1.59 \pm 0.17 \\
(1.2-2.1)\end{array}$ & $\begin{array}{c}1.78 \pm 0.23 \\
(1.2-2.2)\end{array}$ & $\begin{array}{c}1.55 \pm 0.21 \\
(1.2-2.2)\end{array}$ & $\begin{array}{c}1.49 \pm 0.21 \\
(1.0-1.9)\end{array}$ & $\begin{array}{c}1.61 \pm 0.16 \\
(1.4-2.0)\end{array}$ & $\begin{array}{c}1.67 \pm 0.27 \\
(1.1-2.2)\end{array}$ \\
\hline
\end{tabular}


The unfavorable conditions for plant growth in 2019 had a negative impact on all the yield parameters of fibrous flax. Compared to 2020, the average yield for the cultivars studied was $56 \%$ lower, and the differences between the cultivars were statistically insignificant. In 2020, the HDH line had the highest total yield and, compared to the reference cultivars Filea, Novea, Jan, Sara and Modran, these differences were statistically significant. Long-lasting periods of drought in 2019 had the greatest negative impact on the straw yield, which is the most important functional trait of fibrous flax. The average straw yield of the studied cultivars was at a low level, from $27 \mathrm{dt} \mathrm{ha}^{-1}$ to $30 \mathrm{dt} \mathrm{ha}^{-1}$ and was on average as much as $65 \%$ lower compared to 2020 (Figure 2). In both research seasons, no statistically significant differences were found between the $\mathrm{HDH}$ line and other variations in the value of this parameter. However, it is worth emphasizing that, in the favorable flax cultivation season (2020), the straw yield of the HDH line was $8 \%$ higher compared to the best-yielding reference varieties (Filea and Sara), which proves the high yield potential of this line (Table 5).

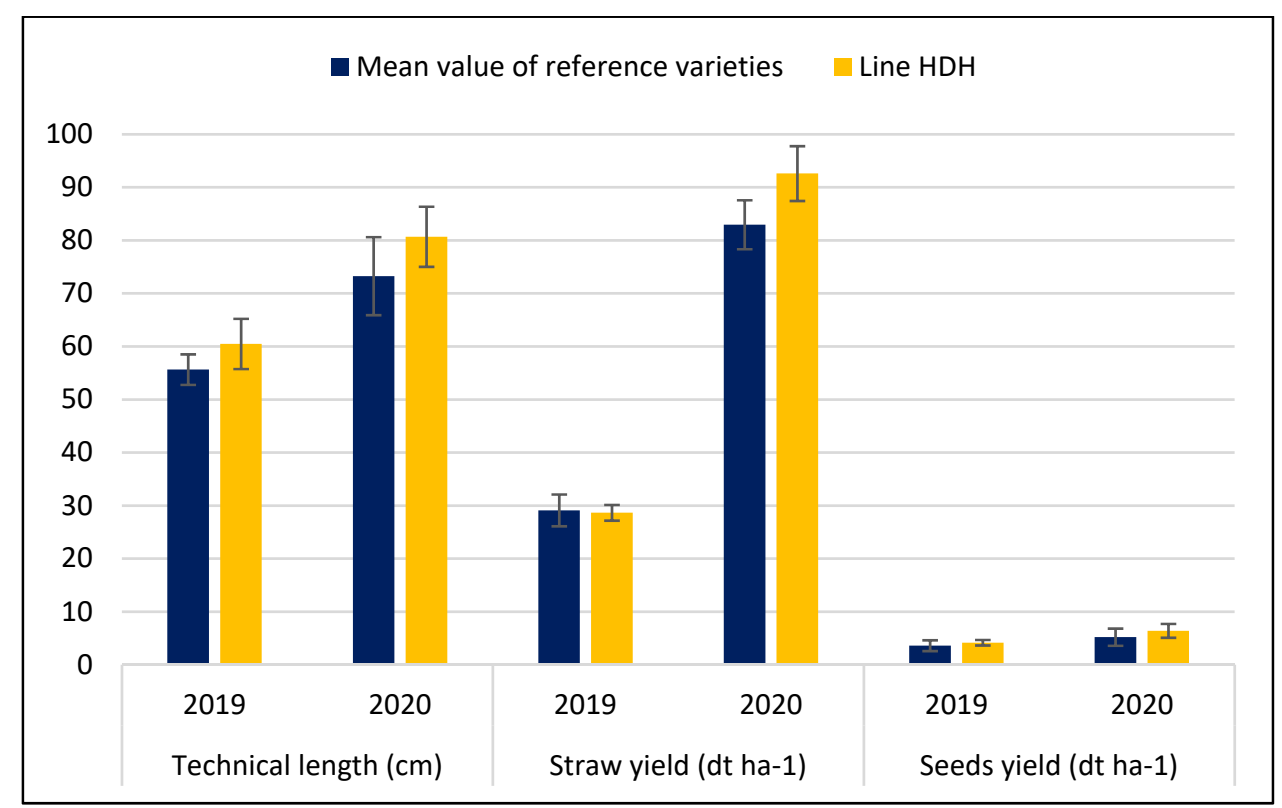

Figure 2. Comparison of the technical length of the stems, straw yield and seed yield of the HDH line with the average values of the seven reference varieties.

In 2019, the seed yields of the studied varieties were low, ranging from $2.93 \mathrm{dt} \mathrm{ha}^{-1}$ to $4.94 \mathrm{dt} \mathrm{ha}^{-1}$. These differences were statistically insignificant. In the favorable season for flax cultivation (2020), the yields of the same varieties ranged from $4.39 \mathrm{dt} \mathrm{ha}^{-1}$ to $6.71 \mathrm{dt} \mathrm{ha}^{-1}$, and also in this case no statistically significant differentiation was found between the cultivars (Table 5). The comparison of the most important functional traits of the new $\mathrm{HDH}$ breeding line in relation to the mean values of all tested reference varieties is presented in Figure 2.

The data presented in Figure 2 confirm that the new HDH line of fibrous flax has a higher yield potential compared to the reference varieties. Good parameters, especially in terms of the technical length of the stems and straw yield, make it possible to conclude that the HDH line is a valuable genotype of the fibrous form of cultivated flax.

\subsection{Field Experiments with Linseed Varieties}

The comparison of the R26 breeding line with the seven reference cultivars was carried out similarly to fibrous flax in two growing seasons with extremely different amounts of precipitation. The R26 line showed overall higher resistance to periodical water shortage in the soil compared to the reference cultivars. In unfavorable weather conditions (2019), the plant height of the R26 line was significantly higher than the five cultivars tested (CJ 1016, 
Altess, Marquise, Merlin, Jantarol), and the panicle length was higher than six cultivars (CJ 1016, Altess, Festival, Marquise, Merlin, Jantarol). In terms of technical length, the R26 line in 2019 was second only to the Festival variant, while it was significantly better than the CJ 1016, Altess, Marquise and Merlin variants (Table 6).

Table 5. Means, standard deviation and ranges for total yield, straw yield and seeds yield of the fibrous flax varieties.

\begin{tabular}{|c|c|c|c|c|c|c|c|c|c|}
\hline \multirow{2}{*}{ Traits } & \multirow{2}{*}{ Year } & \multicolumn{8}{|c|}{ Variety } \\
\hline & & Evea & Filea & Novea & $\mathrm{HDH}$ & Jan & Sara & Modran & Selena \\
\hline \multirow{2}{*}{$\begin{array}{c}\text { Total yield } \\
\left(\mathrm{dt} \mathrm{ha}^{-1}\right)\end{array}$} & 2019 & $\begin{array}{c}41.98 \pm 5.98 \\
(35.56-47.41)\end{array}$ & $\begin{array}{l}39.75 \pm 2.99 \\
(37.04-42.96)\end{array}$ & $\begin{array}{l}39.01 \pm 2.13 \\
(37.78-41.48)\end{array}$ & $\begin{array}{c}42.47 \pm 3.72 \\
(38.52-45.93)\end{array}$ & $\begin{array}{c}43.7 \pm 8.73 \\
(34.07-51.10)\end{array}$ & $\begin{array}{c}44.2 \pm 2.99 \\
(41.48-47.41)\end{array}$ & $\begin{array}{l}43.21 \pm 3.34 \\
(40.00-46.67)\end{array}$ & $\begin{array}{c}44.2 \pm 5.75 \\
(37.78-48.89)\end{array}$ \\
\hline & 2020 & $\begin{array}{l}93.33 \pm 2.95 \\
(90.40-96.30)\end{array}$ & $\begin{array}{l}98.52 \pm 2.20 \\
(96.30-100.7)\end{array}$ & $\begin{array}{l}95.31 \pm 0.87 \\
(94.80-96.30)\end{array}$ & $\begin{array}{c}107.9 \pm 3.00 \\
(104.4-109.6)\end{array}$ & $\begin{array}{l}91.85 \pm 0.75 \\
(91.10-92.6)\end{array}$ & $\begin{array}{l}95.56 \pm 8.15 \\
(87.40-103.7)\end{array}$ & $\begin{array}{l}91.85 \pm 5.95 \\
(85.90-97.80)\end{array}$ & $\begin{array}{l}99.51 \pm 2.80 \\
(96.30-101.5)\end{array}$ \\
\hline \multirow{2}{*}{$\begin{array}{c}\text { Straw yield } \\
\left(\mathrm{dt} \mathrm{ha}^{-1}\right)\end{array}$} & 2019 & $\begin{array}{l}29.63 \pm 4.62 \\
(24.44-33.33)\end{array}$ & $\begin{array}{l}27.16 \pm 1,86 \\
(25.19-28.89)\end{array}$ & $\begin{array}{l}27.65 \pm 1.70 \\
(26.67-29.63)\end{array}$ & $\begin{array}{l}28.15 \pm 1.48 \\
(26.67-29.63)\end{array}$ & $\begin{array}{l}28.64 \pm 4.93 \\
(22.96-31.85)\end{array}$ & $\begin{array}{l}30.12 \pm 2.13 \\
(28.89-32.59)\end{array}$ & $\begin{array}{l}30.37 \pm 1.95 \\
(28.89-32.59)\end{array}$ & $\begin{array}{l}30.12 \pm 3.79 \\
(25.93-33.33)\end{array}$ \\
\hline & 2020 & $\begin{array}{l}82.59 \pm 2.60 \\
(80.00-85.20)\end{array}$ & $\begin{array}{l}85.19 \pm 2.95 \\
(82.20-88.10)\end{array}$ & $\begin{array}{l}83.46 \pm 3.07 \\
(80.00-85.90)\end{array}$ & $\begin{array}{l}92.59 \pm 5.16 \\
(86.70-96.30)\end{array}$ & $\begin{array}{c}80.25 \pm 2.14 \\
(77.80-81.50)\end{array}$ & $\begin{array}{l}85.19 \pm 8.90 \\
(76.30-94.10)\end{array}$ & $\begin{array}{l}80.99 \pm 8.43 \\
(74.10-90.40)\end{array}$ & $\begin{array}{l}82.96 \pm 1.27 \\
(81.50-83.70)\end{array}$ \\
\hline \multirow{2}{*}{$\begin{array}{l}\text { Seed yield } \\
\left(\mathrm{dt} \mathrm{ha}^{-1}\right)\end{array}$} & 2019 & $\begin{array}{l}3.46 \pm 0.84 \\
(2.64-4.33)\end{array}$ & $\begin{array}{l}3.36 \pm 0.41 \\
(3.07-3.83)\end{array}$ & $\begin{array}{l}2.93 \pm 0.33 \\
(2.55-3.19)\end{array}$ & $\begin{array}{l}4.15 \pm 0.51 \\
(3.55-4.46)\end{array}$ & $\begin{array}{l}3.51 \pm 1.60 \\
(1.84-5.05)\end{array}$ & $\begin{array}{l}3.56 \pm 1.19 \\
(2.20-4.43)\end{array}$ & $\begin{array}{l}3.4 \pm 0.88 \\
(2.40-4.07)\end{array}$ & $\begin{array}{l}4.94 \pm 1.04 \\
(3.73-5.62)\end{array}$ \\
\hline & 2020 & $\begin{array}{l}4.05 \pm 0.25 \\
(3.80-4.30)\end{array}$ & $\begin{array}{l}6.16 \pm 0.65 \\
(5.50-6.80)\end{array}$ & $\begin{array}{l}4.98 \pm 2.03 \\
(3.60-7.30)\end{array}$ & $\begin{array}{l}6.38 \pm 1.31 \\
(5.00-7.60)\end{array}$ & $\begin{array}{l}5.52 \pm 2.10 \\
(3.40-7.60)\end{array}$ & $\begin{array}{l}4.57 \pm 0.50 \\
(4.10-5.10)\end{array}$ & $\begin{array}{l}4.39 \pm 1.45 \\
(2.70-5.30)\end{array}$ & $\begin{array}{l}6.71 \pm 2.48 \\
(3.90-8.60)\end{array}$ \\
\hline
\end{tabular}

Details of statistical analyses in Supplementary Materials Tables S9-S14.

Table 6. Means, standard deviation and ranges for total, technical, panicle length and boll number of the linseed.

\begin{tabular}{|c|c|c|c|c|c|c|c|c|c|}
\hline \multirow{2}{*}{ Traits } & \multirow{2}{*}{ Year } & \multicolumn{8}{|c|}{ Variety } \\
\hline & & CJ 1016 & Altess & Festival & Marquise & Merlin & Jantarol & Bukoz & R26 \\
\hline \multirow{2}{*}{$\begin{array}{c}\text { Total } \\
\text { length }(\mathrm{cm})\end{array}$} & 2019 & $\begin{array}{c}41.59 \pm 7.75 \\
(30-65)\end{array}$ & $\begin{array}{c}42.39 \pm 5.20 \\
(33-66)\end{array}$ & $\begin{array}{c}52.93 \pm 6.92 \\
\quad(35-67)\end{array}$ & $\begin{array}{l}42.24 \pm 5.11 \\
\quad(33-56)\end{array}$ & $\begin{array}{c}45.49 \pm 3.78 \\
(35-54)\end{array}$ & $\begin{array}{c}48.91 \pm 4.53 \\
(35-59)\end{array}$ & $\begin{array}{l}52.21 \pm 4.70 \\
\quad(40-63)\end{array}$ & $\begin{array}{c}53.99 \pm 4.48 \\
(38-65)\end{array}$ \\
\hline & 2020 & $\begin{array}{c}57.4 \pm 4.72 \\
\quad(47-70)\end{array}$ & $\begin{array}{c}53.87 \pm 3.58 \\
\quad(47-60)\end{array}$ & $\begin{array}{c}68.37 \pm 4.33 \\
\quad(60-77)\end{array}$ & $\begin{array}{l}55.1 \pm 5.55 \\
\quad(46-66)\end{array}$ & $\begin{array}{c}59 \pm 3.27 \\
(52-65)\end{array}$ & $\begin{array}{l}63.03 \pm 5.20 \\
\quad(54-72)\end{array}$ & $\begin{array}{c}66.13 \pm 6.59 \\
\quad(51-77)\end{array}$ & $\begin{array}{c}63.00 \pm 3.15 \\
\quad(56-70)\end{array}$ \\
\hline \multirow{2}{*}{$\begin{array}{l}\text { Technical } \\
\text { length }(\mathrm{cm})\end{array}$} & 2019 & $\begin{array}{c}30.51 \pm 6.20 \\
\quad(24-53)\end{array}$ & $\begin{array}{c}31.75 \pm 3.97 \\
(22-50)\end{array}$ & $\begin{array}{c}41.8 \pm 5.46 \\
\quad(25-52)\end{array}$ & $\begin{array}{c}30.84 \pm 4.66 \\
\quad(22-44)\end{array}$ & $\begin{array}{c}35.49 \pm 3.58 \\
\quad(27-44)\end{array}$ & $\begin{array}{c}38.03 \pm 4.06 \\
\quad(25-46)\end{array}$ & $\begin{array}{c}39.33 \pm 4.19 \\
(30-50)\end{array}$ & $\begin{array}{c}40.34 \pm 3.74 \\
(27-50)\end{array}$ \\
\hline & 2020 & $\begin{array}{c}45.13 \pm 5.02 \\
(35-60)\end{array}$ & $\begin{array}{c}39.73 \pm 4.38 \\
\quad(31-50)\end{array}$ & $\begin{array}{c}55.8 \pm 3.88 \\
\quad(46-64)\end{array}$ & $\begin{array}{c}44.33 \pm 5.37 \\
(32-55)\end{array}$ & $\begin{array}{c}47.8 \pm 3.52 \\
(41-55)\end{array}$ & $\begin{array}{l}49.77 \pm 4.13 \\
\quad(44-60)\end{array}$ & $\begin{array}{c}50.77 \pm 5.13 \\
\quad(40-58)\end{array}$ & $\begin{array}{c}49.53 \pm 2.39 \\
(45-55)\end{array}$ \\
\hline \multirow{2}{*}{$\begin{array}{c}\text { Panicle } \\
\text { length }(\mathrm{cm})\end{array}$} & 2019 & $\begin{array}{c}11.08 \pm 3.34 \\
(5-20)\end{array}$ & $\begin{array}{c}10.64 \pm 3.61 \\
(3-23)\end{array}$ & $\begin{array}{c}11.13 \pm 4.31 \\
(2-26)\end{array}$ & $\begin{array}{c}11.4 \pm 3.11 \\
\quad(5-20)\end{array}$ & $\begin{array}{c}10 \pm 3.62 \\
(1-23)\end{array}$ & $\begin{array}{c}10.88 \pm 3.55 \\
(2-25)\end{array}$ & $\begin{array}{c}12.88 \pm 4.07 \\
(4-30)\end{array}$ & $\begin{array}{c}13.65 \pm 3.25 \\
(7-21)\end{array}$ \\
\hline & 2020 & $\begin{array}{c}12.27 \pm 2.94 \\
(8-20)\end{array}$ & $\begin{array}{c}14.13 \pm 3.70 \\
\quad(7-21)\end{array}$ & $\begin{array}{c}12.57 \pm 2.10 \\
(9-16)\end{array}$ & $\begin{array}{c}10.77 \pm 2.36 \\
(6-18)\end{array}$ & $\begin{array}{c}11.2 \pm 2.43 \\
\quad(7-18)\end{array}$ & $\begin{array}{c}13.27 \pm 3.55 \\
(6-22)\end{array}$ & $\begin{array}{c}15.37 \pm 3.29 \\
(10-21)\end{array}$ & $\begin{array}{c}13.47 \pm 2.49 \\
(9-17)\end{array}$ \\
\hline \multirow{2}{*}{$\begin{array}{c}\text { Bolls } \\
\text { number }\end{array}$} & 2019 & $\begin{array}{c}15.83 \pm 7.25 \\
(4-39)\end{array}$ & $\begin{array}{c}10.59 \pm 5.55 \\
(2-29)\end{array}$ & $\begin{array}{c}12.2 \pm 4.87 \\
\quad(4-29)\end{array}$ & $\begin{array}{l}11.73 \pm 5.55 \\
\quad(2-27)\end{array}$ & $\begin{array}{c}12.29 \pm 4.69 \\
(3-27)\end{array}$ & $\begin{array}{l}12.93 \pm 4.0 \\
(5-25)\end{array}$ & $\begin{array}{c}14.84 \pm 5.38 \\
(6-31)\end{array}$ & $\begin{array}{c}14.93 \pm 4.89 \\
(5-32)\end{array}$ \\
\hline & 2020 & $\begin{array}{c}11.43 \pm 4.07 \\
(6-25)\end{array}$ & $\begin{array}{c}10.57 \pm 5.38 \\
(5-34)\end{array}$ & $\begin{array}{c}11.23 \pm 3.46 \\
(6-19)\end{array}$ & $\begin{array}{c}9.63 \pm 3.48 \\
(3-20)\end{array}$ & $\begin{array}{c}10.03 \pm 3.98 \\
\quad(4-21)\end{array}$ & $\begin{array}{c}13.07 \pm 5.25 \\
(5-26)\end{array}$ & $\begin{array}{c}13.1 \pm 4.56 \\
(6-21)\end{array}$ & $\begin{array}{c}9.87 \pm 2.52 \\
(6-15)\end{array}$ \\
\hline
\end{tabular}

Details of statistical analyses in Supplementary Materials Tables S15-S22.

In 2019 , the average height of the plants tested in the experimental objects was $78 \%$ of the values observed in 2020, the technical length was $75 \%$, and the average length of the panicle was $88 \%$ of the 2020 values. In this context, the plants of the R26 line were characterized by a less-rapid reaction to water deficits in the soil compared to the observed average. The overall length of the plants of the R26 line in 2019 was 15\% shorter than in 2020, the technical length was 19\% shorter, while the length of the panicle was even slightly longer in dry 2019 than in 2020, which is characterized by favorable weather conditions (Table 6).

The experiment carried out in 2020, a favorable year for flax cultivation, also showed, that the R26 line is a prospective linseed genotype. The average plant height was significantly higher than the four reference varieties: CJ 1016, Altess, Marquise and Merlin. The situation was similar in the case of the technical length, where the average for plants of the R26 line was significantly higher than the CJ 1016, Altess and Marquise cultivars, while also significantly lower only for the Festival cultivar. 
The length of the panicles of the tested cultivars was at a similar level. Significant differences between the R26 line and the reference varieties were found only for the Marquise variety, whose panicle length was significantly lower than that of the R26 line.

The differences in water availability for linseed plants observed in 2019 and 2020 did not have a large impact on the number of seed pods formed. In the dry year of 2019, the average number of pods from all tested genotypes of linseed was even $18 \%$ higher than in 2020. There were no significant differences in the number of developed bolls between Line R26 and other cultivars in 2020. In the growing season of 2019, the number of bolls of the R26 line was significantly higher compared to the Altess and Marquise cultivars, while remaining significantly inferior to any of the other cultivar varieties tested (Table 6).

While maintaining a similar yield in the dry year 2019, the R26 line was characterized by the highest average plant height and panicle length in relation to the reference varieties. As in the case of the traits affecting the total length, technical length and panicle length, also for the yield structure, significantly lower values were observed in 2019 compared to 2020 .

In both research seasons, plants of the R26 line yielded at the level of the reference cultivars. No significant differences were found between the studied objects of experiments, both in terms of the total yield, as well as the yield of straw and seeds (Table 7). In 2019, the yields of the studied varieties were significantly lower. The average total yield of the studied varieties of linseed flax in 2019 was $41 \%$ lower than in 2020, while the straw yield was as much as $53 \%$ lower.

Table 7. Means, standard deviation and ranges for total yield, straw yield and seed yield for the linseed varieties.

\begin{tabular}{|c|c|c|c|c|c|c|c|c|c|}
\hline \multirow{2}{*}{ Traits } & \multirow{2}{*}{ Year } & \multicolumn{8}{|c|}{ Variety } \\
\hline & & CJ 1016 & Altess & Festival & Marquise & Merlin & Jantarol & Bukoz & R26 \\
\hline \multirow{2}{*}{$\begin{array}{l}\text { Total yield } \\
\left(\mathrm{dt} \mathrm{ha}^{-1}\right)\end{array}$} & 2019 & $\begin{array}{c}49.33 \pm 4.51 \\
(45-54)\end{array}$ & $\begin{array}{c}38.00 \pm 9.85 \\
(30-49)\end{array}$ & $\begin{array}{c}41.00 \pm 7.21 \\
(33-47)\end{array}$ & $\begin{array}{c}37.67 \pm 3.21 \\
(34-40)\end{array}$ & $\begin{array}{c}33.33 \pm 2.52 \\
(31-36)\end{array}$ & $\begin{array}{c}36.67 \pm 5.86 \\
(30-41)\end{array}$ & $\begin{array}{c}48.67 \pm 7.37 \\
(43-57)\end{array}$ & $\begin{array}{c}43.00 \pm 3.00 \\
(40-46)\end{array}$ \\
\hline & 2020 & $\begin{array}{c}78.33 \pm 10.10 \\
(67.5-87.5)\end{array}$ & $\begin{array}{c}71.93 \pm 6.77 \\
(65.8-79.2)\end{array}$ & $\begin{array}{c}78.87 \pm 10.73 \\
(70.0-90.8)\end{array}$ & $\begin{array}{c}62.23 \pm 20.40 \\
(41.7-82.5)\end{array}$ & $\begin{array}{c}61.93 \pm 8.36 \\
(54.2-70.8)\end{array}$ & $\begin{array}{c}67.50 \pm 13.99 \\
(56.7-83.3)\end{array}$ & $\begin{array}{c}70.00 \pm 10.42 \\
(60.0-80.8)\end{array}$ & $\begin{array}{c}66.10 \pm 14.04 \\
(50.0-75.8)\end{array}$ \\
\hline \multirow{2}{*}{$\begin{array}{l}\text { Straw yield } \\
\left(\mathrm{dt} \mathrm{ha}^{-1}\right)\end{array}$} & 2019 & $\begin{array}{c}15.67 \pm 2.08 \\
(14-18)\end{array}$ & $\begin{array}{l}17.67 \pm 2.52 \\
\quad(15-20)\end{array}$ & $\begin{array}{l}21.67 \pm 5.03 \\
\quad(17-27)\end{array}$ & $\begin{array}{c}15.33 \pm 1.53 \\
(14-17)\end{array}$ & $\begin{array}{c}16.00 \pm 1.00 \\
(15-17)\end{array}$ & $\begin{array}{c}16.67 \pm 2.52 \\
(14-19)\end{array}$ & $\begin{array}{c}21.00 \pm 3.61 \\
(18-25)\end{array}$ & $\begin{array}{c}20.00 \pm 2.00 \\
(18-22)\end{array}$ \\
\hline & 2020 & $\begin{array}{c}40.83 \pm 8.78 \\
(32.50-50.00)\end{array}$ & $\begin{array}{l}35.00 \pm 3.66 \\
(32.50-39.20)\end{array}$ & $\begin{array}{c}43.33 \pm 5.83 \\
(39.20-50.00)\end{array}$ & $\begin{array}{l}30.57 \pm 10.84 \\
(19.20-40.80)\end{array}$ & $\begin{array}{l}33.33 \pm 4.15 \\
(29.20-37.50)\end{array}$ & $\begin{array}{c}36.97 \pm 6.48 \\
(31.70-44.20)\end{array}$ & $\begin{array}{c}42.23 \pm 5.71 \\
(35.80-46.70)\end{array}$ & $\begin{array}{l}41.97 \pm 10.40 \\
(31.70-52.50)\end{array}$ \\
\hline \multirow{2}{*}{$\begin{array}{c}\text { Seed } \\
\text { yield } \\
\left(\mathrm{dt} \mathrm{ha}^{-1}\right)\end{array}$} & 2019 & $\begin{array}{l}20.21 \pm 2.50 \\
(18.27-23.03)\end{array}$ & $\begin{array}{l}11.46 \pm 3.17 \\
(9.38-15.11)\end{array}$ & $\begin{array}{l}10.83 \pm 0.93 \\
(9.79-11.56)\end{array}$ & $\begin{array}{c}15.00 \pm 2.34 \\
(12.32-16.61)\end{array}$ & $\begin{array}{l}10.09 \pm 0.40 \\
(9.76-10.53)\end{array}$ & $\begin{array}{c}13.14 \pm 2.03 \\
(10.90-14.86)\end{array}$ & $\begin{array}{c}14.66 \pm 3.71 \\
(11.04-18.46)\end{array}$ & $\begin{array}{c}14.05 \pm 2.49 \\
(11.96-16.81)\end{array}$ \\
\hline & 2020 & $\begin{array}{c}17.17 \pm 3.20 \\
(13.70-20.00)\end{array}$ & $\begin{array}{c}19.27 \pm 1.65 \\
(17.60-20.90)\end{array}$ & $\begin{array}{c}19.23 \pm 2.80 \\
(16.80-22.30)\end{array}$ & $\begin{array}{l}15.40 \pm 5.92 \\
(9.80-21.60)\end{array}$ & $\begin{array}{c}15.03 \pm 2.58 \\
(12.90-17.90)\end{array}$ & $\begin{array}{c}17.77 \pm 5.40 \\
(14.50-24,00)\end{array}$ & $\begin{array}{c}17.90 \pm 2.95 \\
(16.10-21.30)\end{array}$ & $\begin{array}{c}17.40 \pm 0.72 \\
(16.60-18.00)\end{array}$ \\
\hline
\end{tabular}

Details of statistical analyses are in the Supplementary Materials, Tables S23-S28.

The procedure of assessing the utility value of new varieties takes into account their comparison with the average values of the reference varieties. In this comparison, the R26 line was an interesting genotype both in terms of traits typical for oily forms and for dual purpose flax forms, characterized by a high yield of seeds and straw. Moreover, the plants of the R26 line exceed the average of the reference varieties in terms of technical length (Figure 3). 


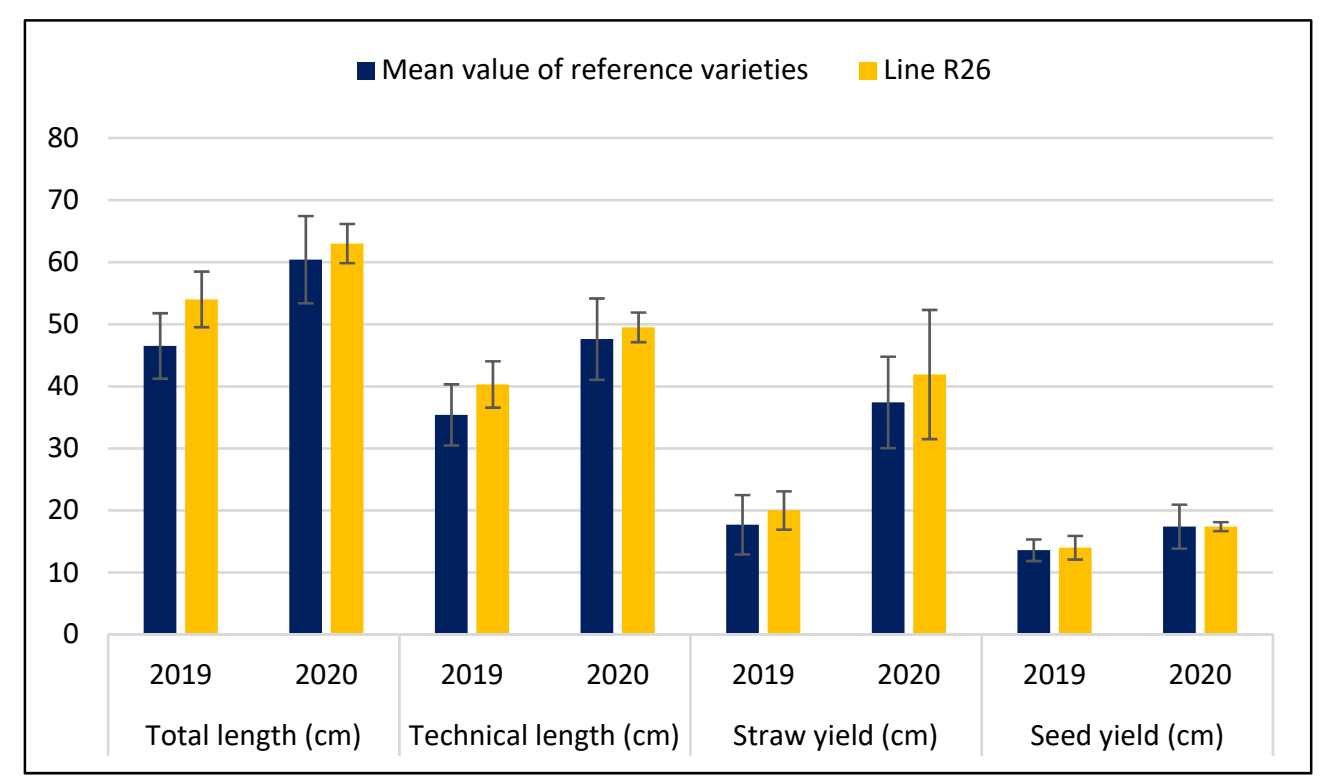

Figure 3. Comparison of plant height, length of stems, panicle length, straw yield and seed yield of the R26 line with the average values of seven reference varieties.

\section{Discussion}

The presented research concerned the comparison of the advanced lines of HDH fibrous flax and R26 linseed with reference varieties in order to determine the economic value of genotypes obtained as a result of breeding works of the IWNiRZ-the Institute of Natural Fibers and Medicinal Plants-National Research Institute (Wielkopolska district, Poland). The comparison was made in terms of total yield, straw yield, seed yield, plant height, technical length and panicle length. The HDH line was additionally confronted with the reference varieties in terms of the stem diameter, while the R26 line was in terms of the number of created seed capsules.

The selection of comparative traits was made on the basis of their significant impact on the economic value of flax varieties and their mutual correlations. Determining the interaction of individual traits and the influence of component traits on the most economically significant traits enables a reliable assessment of the potential of the studied lines and is the basis of all breeding programs $[16,17]$. The mutual and close connection of many functional traits of flax is confirmed in numerous literature reports. In their research, Diederichsen and Ulrich [18] observed the relationship between plant height and fiber content. Moreover, they recorded the highest fiber content in genotypes with a low number of branches. In turn, Gamal et al. found positive correlations between plant height and technical length, as well as technical length and straw yield [19]. Plant height is also known to be closely related to the straw yield [20]. It is therefore also obvious that there is a high relationship between the fiber yield and the technical length and straw yield. The influence of many characteristics (traits) on the seed yield is also direct. Witkowicz et al. report that the yield of flax seeds is determined mainly by four components of the structure: the number of branches, the number of capsules, the number of seeds in the pods and the thousand seeds weight [21]. In turn, Copur et al. observed significant positive correlations between the seed yield and 1000 seeds weight, plant height, number of capsules and the number of branches, while significant negative correlations were observed between the weight of 1000 seeds and the number of seeds in the capsules [22]. Thus, agricultural traits have a direct and significant impact on the final utility value of flax varieties.

For fibrous flax, the technical length, the diameter of the stems and the straw yield are particularly important because they significantly influence the fiber yield, which is the basic goal of cultivar breeding. [22,23]. The conducted experiments showed that plants of the HDH fibrous flax line, both in conditions of sufficient water availability and under 
drought stress, were characterized by higher overall and technical length compared to the reference cultivars. The HDH line also showed a high total yield and straw yield, which is confirmed by reports in the literature on the positive correlation of these traits. It can therefore be concluded with a high degree of probability that the HDH line also has a high potential for fiber content and yield. The high value of the HDH line, confirmed in the conducted experiments, allows it to state that after the registration process it will be a new, valuable variety of fibrous flax.

The comparison of the R26 line with the reference of linseed cultivars showed that it does not significantly exceed the standard in terms of the most important functional traits for linseed. In the case of the seed yield, no significant differences were found between the R26 line and the reference cultivars. The differences in the number of capsules were also insignificant in the vast majority of cases. The conducted experiments also did not fully confirm the positive correlation between the seed yield and the number of capsules previously observed by Copur et al. [24]. This relationship occurred only in 2019 with unfavorable weather conditions for flax cultivation.

The obtained results allow us to conclude about the high potential of the R26 line as a component for dual-purpose cultivars of flax. Not inferior to the reference cultivars in a significant way in terms of yield, the plants of the R26 line were characterized by high values of the total and technical length and the length of the panicle. Referring to the previously described correlations, especially between plant height and straw yield and fiber content, it can be concluded that the R26 line is a valuable genotype for breeding work aimed at obtaining varieties combining high seed yield with high straw and fiber yield. Varieties of flax showing such properties are called dual purpose flax. The breeding of dual-purpose varieties of flax is a research field that has been known for many years. In Poland during the 1970s, the so-called combined varieties were bred [25]. In the breeding works of that time, however, the basis was the fibrous form, in which an attempt was made to increase the seed yield, keeping high yield and long-fiber quality as priority traits. However, the lines obtained in this way did not show high economic value. Increasing the seed yield in fibrous varieties resulted in a decrease in the yield and quality of long fiber; therefore, further work in this direction was abandoned. The breeding of varieties, which is now successfully developing in many countries, differs from that described above. It aims to obtain genotypes characterized primarily by a high yield of seeds with good-quality properties, especially high fat content and a health-promoting profile of polyunsaturated fatty acids. In the lines with high yield and seed quality, attempts are being made to increase the straw yield and the yield of one-type (homomorphic) fiber $[11,26]$. The cultivation of dual-purpose varieties of flax is more profitable compared to the cultivation of strictly fibrous and oily varieties. It enables the efficient use of whole plants. Demand for flax fiber is currently very limited by competition from synthetic fibers and cotton. In addition, the possibility of selling flax fiber at an appropriate price depends on the high quality of the raw material, which, due to the ecological limitations in the retting process and the high dependence of the fiber quality on climatic conditions, is often difficult to achieve. On the other hand, flax fiber used for technical purposes, such as the production of biocomposites or disinfection mats, is becoming more and more popular. Fiber devoted to technical purposes does not have to meet such high quality requirements (as it concerns textile fiber), which significantly increases the possibility of its sale and, consequently, obtaining higher financial profits for growers [27]. The cultivation of dual-purpose varieties also makes it possible to simplify the equipment for harvesting the yield from the field and reduce its costs. Plants can be harvested in the period of full maturity of seeds, additionally using decorticated fiber as a usable raw material.

In the conducted experiments, the R26 line was yielded at the level of the reference cultivars, both under favorable conditions for flax cultivation, as well as under water deficiency in the soil. It concerned the seed yield, as well as the straw yield and the total yield. Plants of the R26 line were characterized by high values of the total length, technical length and panicle length, especially noticed in the unfavorable, dry year of 2019. The 
obtained results allow us to conclude that the R26 line is a prospective genotype for further breeding program for obtaining a valuable dual purpose flax variety.

The conducted experiments also showed the relatively high resistance of the $\mathrm{HDH}$ and R26 lines to water deficit in the soil. While yielding at the level of reference varieties, they were characterized by the highest plants and favorable plant habit. The problem of drought in the cultivation of flax is one of the greatest challenges today. Flax plants, due to their root system, are highly susceptible to water deficiency in the soil. This is especially true of fibrous forms. The unfavorable rainfall distribution observed more and more often in many countries during the growing season of plants leads to a significant reduction in flax yielding and large losses for growers. Varieties with increased resistance to drought are therefore searched for by farmers, and the identification of such genotypes is an extremely important stage in the process of breeding future varieties [28].

Based on the research results presented in the article, the $\mathrm{HDH}$ line was submitted to the Research Centre For Cultivars Testing (COBORU) in order to carry out the registration process as a new variety of flax. After obtaining positive results, the variety will be entered into the European register of varieties of arable crops. The R26 line will be included in the further breeding work of the Institute of Natural Fibers and Medicinal PlantsNational Research Institute in Poznań as a prospective parental form for obtaining dualpurpose lines.

Supplementary Materials: The following are available online at https://www.mdpi.com/article/ 10.3390/agronomy11101917/s1, Table S1: Post hoc test for total length of the reference fiber flax varieties and HDH line in vegetation period 2019; Table S2: Post hoc test for total length of the reference fiber flax varieties and HDH line in vegetation period 2020; Table S3: Post hoc test for technical length of the reference fiber flax varieties and HDH line in vegetation period 2019; Table S4: Post hoc test for technical length of the reference fiber flax varieties and HDH line in vegetation period 2020; Table S5: Post hoc test for panicle length of the reference fiber flax varieties and HDH line in vegetation period 2019; Table S6: Post hoc test for panicle length of the reference fiber flax varieties and HDH line in vegetation period 2020; Table S7: Post hoc test for stem diameter of the reference fiber flax varieties and HDH line in vegetation period 2019; Table S8: Post hoc test for stem diameter of the reference fiber flax varieties and $\mathrm{HDH}$ line in vegetation period 2020; Table S9: Welch test for total yield of the reference fibre flax varieties and $\mathrm{HDH}$ line in vegetation period 2019; Table S10: Post hoc test for total yield of the reference fiber flax varieties and HDH line in vegetation period 2020; Table S11: Welch test for straw yield of the reference fibre flax varieties and HDH line in vegetation period 2019; Table S12: Welch test for straw yield of the reference fiber flax varieties and HDH line in vegetation period 2020; Table S13: Welch test for seed yield of the reference fiber flax varieties and HDH line in vegetation period 2019; Table S14: Welch test for seed yield of the reference fiber flax varieties and HDH line in vegetation period 2020; Table S15: Post hoc test for total length of the reference linseed varieties and R26 line in vegetation period 2019; Table S16: Post hoc test for total length of the reference linseed varieties and R26 line in vegetation period 2020; Table S17: Post hoc test for technical length of the reference linseed varieties and R26 line in vegetation period 2019; Table S18: Post hoc test for technical length of the reference linseed varieties and R26 line in vegetation period 2020; Table S19: Post hoc test for panicle length of the reference linseed varieties and R26 line in vegetation period 2019; Table S20: Post hoc test for panicle length of the reference linseed varieties and R26 line in vegetation period 2020; Table S21: Post hoc test for bolls number of the reference linseed varieties and R26 line in vegetation period 2019; Table S22: Post hoc test for bolls number of the reference linseed varieties and R26 line in vegetation period 2020; Table S23: Welch test for total yield of the reference linseed varieties and R26 line in vegetation period 2019; Table S24: Welch test for total yield of the reference linseed varieties and R26 line in vegetation period 2020; Table S25: Welch test for straw yield of the reference linseed varieties and R26 line in vegetation period 2019; Table S26: Welch test for straw yield of the reference linseed varieties and R26 line in vegetation period 2020; Table S27: Post hoc test for seed yield of the reference linseed varieties and R26 line in vegetation period 2019; Table S28: Welch test for seed yield of the reference linseed varieties and R26 line in vegetation period 2020. 
Author Contributions: Conceptualization, M.P.; methodology, M.P.; investigation, M.P. and K.W.; writing, M.P.; supervision, M.P.; funding acquisition, M.P. All authors have read and agreed to the published version of the manuscript.

Funding: This research was funded by the Polish Ministry of Agriculture and Rural Development, contract number: $171 / 2017$.

Institutional Review Board Statement: Not applicable.

Informed Consent Statement: Not applicable.

Data Availability Statement: The data presented in this study are available on request from the corresponding author.

Acknowledgments: The authors thanks Katarzyna Marcinkowska from the Institute of Plant Protection in Poznan, Poland for help in editorial work in preparing the manuscript for printing.

Conflicts of Interest: The authors declare no conflict of interest.

\section{References}

1. Kajla, P.; Sharma, A.; Sood, D.R. Flaxseed-A potential functional food source. J. Food Sci. Technol. 2015, 52, 1857-1871. [CrossRef]

2. de Silva, S.; Franklyn, A.J. Flaxseed lignans as important dietary polyphenols for cancer prevention and treatment: Chemistry, pharmacokinetics, and molecular targets. Pharmaceuticals 2019, 12, 68. [CrossRef] [PubMed]

3. Sung, N.Y.; Jeong, D.; Shim, Y.Y.; Ratan, Z.A.; Jang, Y.J.; Reaney, M.J.T.; Lee, S.; Lee, B.H.; Kim, J.H.; Yi, Y.S.; et al. The anti-cancer effect of Linusorb B3 from flaxseed oil through the promotion of apoptosis, inhibition of actin polymerization and suppression of Src activity in Glioblastoma Cells. Molecules 2020, 25, 5881. [CrossRef] [PubMed]

4. Parikh, M.; Maddaford, T.G.; Austria, J.A.; Aliani, M.; Netticadan, T.; Pierce, G.N. Dietary flaxseed as a strategy for improving human health. Nutrients 2019, 11, 1171. [CrossRef] [PubMed]

5. Yinghua, T.; Xiaolan, L.; Xiqun, Z.; Lu, W. Antimicrobial properties of flax fibers in the enzyme retting process. Fibres Text. East. Eur. 2016, 1, 15-17.

6. Cao, Y.; Chan, F.; Chui, Y.H.; Xiao, H. Characterization of flax fibres modified by alkaline, enzyme and steam-heat treatments. BioResources 2012, 7, 4109-4121.

7. Zimniewska, M.; Rozańska, W.; Gryszczynska, A.; Romanowska, B.; Kicinska-Jakubowska, A. Antioxidant potential of hemp and flax fibers depending on their chemical composition. Molecules 2018, 23, 1993. [CrossRef] [PubMed]

8. FAOSTAT. Available online: http:/ / www.fao.org (accessed on 26 May 2021).

9. Easson, D.L. A study of the plant, fibre and seed development in flax and linseed (Linum usitatissimum) grown at a range of seed rates. J. Agric. Sci. 2000, 135, 361-369. [CrossRef]

10. Pavelek, M.; Vrobova-Prokopova, M.; Ondrackova, E.; Ludvikova, M.; Griga, M. Developments in fibrous flax and linseed breeding and cultivation. In Handbook of Natural Fibres, 2nd ed.; Woodhead Publishing: Sawston, UK, 2020; Volume 19, pp. 1-95.

11. Sharma, A.K.; Gawande, S.P.; Satpathy, S. Stay green trait in flax: A new horizon for dual purpose flax cultivation in Assam. Curr. Biot. 2015, 9, 90-92.

12. Fila, G.; Bagatta, M.; Maestrini, C.; Potenza, E.; Matteo, R. Linseed as a dual-purpose crop: Evaluation of cultivar suitability and analysis of yield determinants. J. Agric. Sci. 2018, 156, 162-176. [CrossRef]

13. Pandey, R. Fiber extraction from dual-purpose flax. J. Nat. Fibers 2016, 13, 565-577. [CrossRef]

14. Fu, Y.B. Geographic patterns of RAPD variation in cultivated flax. Crop Sci. 2005, 45, 1084-1091. [CrossRef]

15. Fu, Y.B.; Diederichsen, A. Phenotypic and molecular (RAPD) differentiation of four intraspecific groups of cultivated flax (Linum usitatissimum subs. usitatissimum). Genet. Resour. Crop Evol. 2006, 53, 77-90.

16. Pavelek, M.; Tejklova, E.; Horacek, J. Flax national collection, international flax data base and breeding of flax, linseed and both types in the Czech Republic. Nat. Fibres 2001, 1, 64-78.

17. Singh, N.; Yadav, V.K.; Kumar, R.; Kumar, S.; Yadav, H.K. Genetic variability and interrelationship among morphological and yield traits in linseed (Linum usitatissimum L.). Genetika 2016, 48, 881-892.

18. Diederichsen, A.; Ulrich, A. Variability in stem fibre content and its association with other characteristics in 1177 flax (Linum usitatissimum L.) genebank accessions. Ind. Crops Prod. 2009, 30, 33-39. [CrossRef]

19. El-Shimy, G.H.; Abd Al-Sadek, M.S.; Abd El-Haleem, R.A. Comparative analysis of yield and anatomical manifestations of six flax genotypes. Egypt. J. Agric. Res. 2015, 93, 67-84.

20. Stafecka, I.; Stramkale, V.; Kroica, I.; Starmkalis, A. The evaluation of yield and agronomic traits of flax genotypes under latvian conditions. In Environment Technology Resources, Rezekne, Latvia. Proceedings of the 12th International Scientific and Practical Conference; Rezekne Academy of Technologies: Rēzekne, Latvia, 2019; Volume 1, pp. 277-282. Available online: www.journals.ru.lv (accessed on 26 May 2021).

21. Witkowicz, R.; Zając, T.; Kryńska, B.; Klima, K. Zmienność i współzależność komponentów struktury plonu nasion lnu oleistego. Acta Agrar. Silvestria. Ser. Agrar. 2005, XLV, 11-16. 
22. Wang, Y.F.; Jankauskiene, Z.; Qiu, C.S.; Gruzdeviene, E.; Long, S.H.; Alexopoulou, E. Fiber flax breeding in China and Europe. J. Nat. Fibers 2018, 15, 309-324. [CrossRef]

23. Porsev, I.; Sozinov, A.; Karpov, G.; Salomatina, K. Promising varieties of fiber and oil flax plants for agricultural technologies of Trans-Urals. BIO Web Conf. 2020, 27, 00096. [CrossRef]

24. Copur, O.; Atill-Gur, M.; Karakus, M.; Demirel, U. Determination of correlation and path analysis among yield components and seed yield in oil flax varieties (Linum usitatissimum L.). J. Biol. Sci. 2006, 6, 738-743.

25. Zajac, T.; Oleksy, A.; Klimek-Kopyra, A.; Kulig, B. Biological determinants of plant and crop productivity of flax (Linum usitatissimum L.). Acta Agrobot. 2012, 65, 3-14. [CrossRef]

26. Singh, P.K.; Chopra, P. Double purpose linseed: A viable option for doubling farmers income in the north-western Himalayan region. Ind. Farm. 2018, 68, 49-54.

27. Zimniewska, M.; Zbrowski, A.; Konczewicz, W.; Majcher, A.; Przybylski, J.; Matecki, K.; Wiśniewski, M.; Jakubowska-Kicińska, A.; Mańkowski, J. Cottonisation of decorticated flax fibres. Fibres Text. East. Eur. 2017, 25, 26-33. [CrossRef]

28. Soto-Cerda, B.; Cloutier, S.; Gajardo, H.A.; Aravena, G.; Quian, R. Identifying drought-resilient flax genotypes and relatedcandidate genes based on stress indices, root traits and selective sweep. Euphytica 2019, 215, 41. [CrossRef] 